\title{
An Evaluation on CSR Expenditures and Its Relationship with Financial Performance Variables of the Nationalized Commercial Banks (NCBs) in Bangladesh
}

\author{
Mst. Hasna Banu ${ }^{1}$, Aditi Sonia Aishi², Taposh Kumar Neogy ${ }^{3^{*}}$
}

${ }^{1}$ Assistant Professor, Department of Accounting and Information Systems, University of Rajshahi, Rajshahi-6205, BANGLADESH

${ }^{2}$ BSS (Hons), MSS, Department of Economics, University of Rajshahi, Rajshahi-6205, BANGLADESH

${ }^{3}$ Assistant Professor in Accounting, Institute of Business Administration (IBA), Rajshahi (under National University), BANGLADESH

Corresponding Contact:

Email: neogyais@gmail.com

Manuscript Received: 28 Dec $2018 \quad$ - Revised: 21 Feb 2019 - Accepted: 03 March 2019

\begin{abstract}
At present corporate social responsibility (CSR) has become an important tool due to contribute the sustainable economic development by ensuring the different benefits for the stakeholders. Corporate social responsibility (CSR) expenditures are extending accepted issue for economic development in competitive business world. The study examines the corporate social responsibility (CSR) expenditures and its relationship with financial performance variables of the sample banks between the years 2012 to 2016 with the use of secondary data. Findings from the analysis display that the sample banks have contributed in the different activities under corporate social responsibility (CSR) program but the contributions were not sufficient over the study period. The study revealed that the corporate social responsibility (CSR) expenditures of the sample banks have shown increasing and decreasing tendency during the study period. The study also revealed that there is no significant influence of financial performance variables on corporate social responsibility (CSR) expenditures of the sample banks over the study period.
\end{abstract}

Key Words: CSR, Financial Performance, Nationalized Commercial Banks, Bangladesh

\section{INTRODUCTION}

The success of every business depends largely on the positive impact of the organization on the stakeholders and the environment of the hosting community. Positive response to environmental and social issues by way of accounting and communication they leave the investors with the confidence that the organization they are dealing with transparent (Begum et al., 2012). Corporate social responsibility (CSR) is an action taken by the company as a sense of 
social responsibility to the company and the environment in which they operate, as do an activity that can improve the welfare of local communities and protecting the environment. Corporate social responsibility (CSR) is a phenomenon and strategies that companies use to accommodate the needs and interests of its stakeholders. The business world is growing rapidly, demanding the company's competence in maintaining their business. In developing a business enterprise requires not only investors who will invest in the company, but also needed a good relationship with the government and society (Ahmed, 2009). Recently corporate social responsibility (CSR) is one of the most debated issues all over the world and it has gained much attention among the research community as well as government, law makers, politicians, business people, civil society, social workers and NGOs. The idea of corporate social responsibly (CSR) first evolves in 1953 when it became an academic topic in HR Bowen's "Social Responsibilities of the Business". Bowen gave an initial definition of the social responsibility of businessmen. It refers to the obligations of businessmen to pursue those policies, to make those decisions, or to follow those lines of action which are desirable in terms of the objectives and values of our society (Khatun, 2014). Corporate social responsibilities (CSR) are an assurance of the organizations to action morally and add to financial progress of the people while improving the worth of the life of the employees and the local public in general and it is essential for the organizations to confirm its sustainability though corporate social responsibility (CSR) is a global issue and all organizations practice it to some degree. Corporate social responsibilities (CSR) have become a standard of generally legitimate corporate effort and the acceptance of it is rising gradually. Corporate social responsibilities can be observed as an all-inclusive set of strategies, observations, and programs that are combined into corporate actions, resource chains, and assessment making procedures through the corporation and comprise duties for present and past activities along with sufficient devotion to future effects (Ferdous, 2015). At present corporate social responsibility (CSR) is a prime concern to the society and it considers one of the most powerful instruments to acquire the competitive advantage among different competitors. Now corporate social responsibility (CSR) is closely related with modern business for this reason every company incurs good and big amount of money for the corporate social responsibility (CSR) purposes of every year. The Bangladesh Bank is now very concern about the corporate social responsibility (CSR) activities for this reason Bangladesh Bank gives some directions for the improvement of corporate social responsibility (CSR) activities practices (Ferdous and Moniruzzaman, 2013). The concept of corporate social responsibility (CSR) generally means the social and local development of the community and taking initiative to conserve the environment and culture. Corporate social responsibility (CSR) in Bangladesh can contribute a lot to community development. The corporate house can develop the community by creating employment, providing primary education, contribution to infrastructure development like roads and highways and addressing environmental concerns. Corporate social responsibility (CSR) practices by them not only improve their own standards but also revolutionize the socially responsible actions of other business (Mohammad and Kamal, 2016). An acceptable level of corporate social responsibility (CSR) depends on to promote the good corporate governance. As a member of the global economy, Bangladesh needs to give more emphasis on devising policies and regulations to make business organizations environmentally and socially responsible. Since every company operates with the society, they have the responsibility toward the society and the extent of this responsibility should be determined by the nature of the industry under which they are operating (Yesmine and Bhuiyah, 2015). Corporate social responsibility (CSR) is the concept that an organization needs to consider its impact on their operations and business practices on not just the shareholders, but also its customers, suppliers, employees, members of the community it operates in, and even the environment. Advocates of corporate social responsibility (CSR) argue that companies with good social and environmental records will 
perform better in the long run (Gololo, 2016). Today, corporate leaders face a dynamic and challenging task in attempting to apply societal ethical standards to responsible business practice. Corporate social responsibility (CSR) asserts that corporations have an obligation to consider the interest of customers, employees, shareholders, communities in all aspects of their operations (Abiodun, 2012). Nowadays, the corporate social responsibility (CSR) is a worldwide concern and it is a matter of regret that it still is witnessed widely international arena, but in Bangladesh, it is lagging behind relating to developed states of the world. Sustainable growth is not possible without the assistance of the business world. Corporate social responsibility (CSR) is integral and inseparable part of the long term business and sustainable growth and success, which plays an important role in promoting values both locally and internationally and usually, is noticed as a developed country sensation. All over the world, a corporate social responsibility (CSR) is essential for the organizations to confirm its sustainability (Roy et al., 2017).

\section{Relationship with Financial Performance Variables}

At present banking industry is the most flourishing as well as contributing sector of any economy. Banking sector is the driving force of any country for her sustainable development. It is more than truth for a developing country like ours. Currently in Bangladesh the spread of bank branches to the rural areas is increasing the banking habit of people. People keep their excess money in banks and withdraw at the time of need. This leads to the monetization of rural areas (Hossain and Sultana, 2014).The financial statements are the main tool for external and internal stakeholders to measure the management performance. An important component in the financial statements which are often used as a tool to inform management performance is the net income. Therefore, profit is an indicator of the corporate financial performance and it might also be used by stakeholders as a basis for economic decision making and to endure the continuity of their main interests in the company (Haldar and Rahman, 2015). The primary objective of financial manager in theory of finance is to maximize shareholder's wealth but the phenomenon which covers ethical, social and environment protection related duties of companies is called corporate social responsibility (CSR). Financial institutions like banks are playing key role in corporate social responsibility (CSR) engagements. Corporate social responsibility (CSR) is not a new thing of interest for businesses in the world as well as is important because it influence all aspects of bank's operations (Ashraf et al., 2017). The involvement in socially responsible initiatives has a significantly positive effect on financial performance and it is important to incorporate a longer period in order to validate the positives relationship between corporate social responsibility (CSR) and financial performance (Giannarakis et al., 2016). A stakeholder oriented firm while generating value for its stakeholders also generated value for its shareholders. A favorable aggregate corporate social responsibility (CSR) towards all the primary stakeholders creates a fleet of satisfied stakeholders who bring in efficiency gains and cost advantages through various means that ultimately improve firm performance (Mishra and Suar, 2010). The corporate social responsibility (CSR) expenditures assist to improve the financial performance and banks get directly or indirectly benefit from corporate social responsibility (CSR) expenditures. The main attempt of this discussion is to measure the corporate social responsibility (CSR) expenditures and its relationship with financial performance variables of the sample banks. For this reason researchers have focused the different activities of corporate social responsibility (CSR) expenditures (CSR) and the different aspects of financial performance. In order to see whether there is any relationship between corporate social responsibility (CSR) expenditures and the financial performance variables, researchers have considered some variables which are indicators to measure the financial performance and these are: net profit; total deposits; total assets; total investments; return on assets; return on equity and earnings per share. 


\section{Objectives of the Study}

This research study displays the issue of corporate social responsibility (CSR) expenditures and its relationship with the financial performance variables. With a view to achieving the main objective of this research study researchers have considered the following specific objectives:

- To examine total contributions in different years under corporate social responsibility (CSR) program of the sample nationalized commercial banks in Bangladesh.

- To evaluate the relationship between corporate social responsibility (CSR) expenditures and the financial performance variables of the sample nationalized commercial banks in Bangladesh.

\section{Hypothesis of the Study}

Researchers have developed the following null hypotheses and these are pertained with the research objectives.

Ho1: There is no significant difference between the total corporate social responsibility (CSR) expenditures of the sample nationalized commercial banks in Bangladesh.

Ho2: There is no significant influence of financial performance variables on corporate social responsibility (CSR) expenditures of the sample nationalized commercial banks in Bangladesh.

\section{Data And Methodology of the Study}

In this study, researchers have analyzed the corporate social responsibility (CSR) expenditures and the financial performance variables of four nationalized commercial banks like Sonali Bank Limited (here in after Sample Bank_1), Agrani Bank Limited (here in after Sample Bank_2), Janata Bank Limited (here in after Sample Bank_3) and Rupali Bank Limited (here in after Sample Bank_4). In order to achieve the research objectives of the study, the secondary data have been used and collected from the secondary sources mostly from annual reports. This study has examined for the period five years starting from 2012 to 2016. As a requirement of analysis of this research study researchers have considered dependent and independent variables. This research study has used corporate social responsibility (CSR) expenditures as dependent variable as well as net profit, total assets, total deposits, total investment, return on equity, return on assets and earnings per shares as independent variables because corporate social responsibility (CSR) expenditures depended on above mentioned different financial performance variables. This present research study has used mean, standard deviation, coefficient of variation, $t$ test and regression analysis for analyzing the collected data.

\section{RESULTS AND DISCUSSION}

In order to achieve the different research objectives of the present research study researchers have examined the different audited annual reports of the respective sample nationalized commercial banks in Bangladesh. The following tables provide the year wise total corporate social responsibility (CSR) expenditures and the influence of financial performance variables on corporate social responsibility expenditures of the respective sample banks over the study period.

\section{Paired Sample $t$ test}

The following results of paired sample $t$ test of the sample banks over the study period from 2012 to 2016 have obtained by the using of SPSS program. 
Table 1: Table showing the total contributions in different years under corporate social responsibility (CSR) program of the sample banks during the years from 2012 to 2016

(Taka in Million)

\begin{tabular}{|c|c|c|c|c|c|c|}
\hline Sample Banks & $\mathbf{2 0 1 2}$ & $\mathbf{2 0 1 3}$ & $\mathbf{2 0 1 4}$ & $\mathbf{2 0 1 5}$ & $\mathbf{2 0 1 6}$ & Total \\
\hline Sample Bank_1 & 26.30 & 49.10 & 45.20 & 65.70 & 12.53 & 198.83 \\
\hline Sample Bank_2 & 53.31 & 83.72 & 64.56 & 31.65 & 24.51 & 257.75 \\
\hline Sample Bank_3 & 113.37 & 291.50 & 138.42 & 22.40 & 9.13 & 574.82 \\
\hline Sample Bank_4 & 15.29 & 32.18 & 30.79 & 8.74 & 11.68 & 98.68 \\
\hline Average & 52.07 & 114.13 & 69.74 & 32.12 & 14.46 & 282.52 \\
\hline SD & 43.88 & 120.18 & 47.83 & 24.28 & 6.85 & 205.63 \\
\hline CV & 84.27 & 105.31 & 68.58 & 75.59 & 47.38 & 72.79 \\
\hline Total & 208.27 & 456.50 & 278.97 & 128.49 & 57.85 & 1130.08 \\
\hline
\end{tabular}

(Source: Compilation of Annual Reports of Sample Banks)

Table 1 displays the total corporate social responsibility (CSR) contributions in the different years of the sample banks during the study period. The average corporate social responsibility (CSR) contribution of the sample banks is 282.52 million, SD is 205.63 million and CV is 72.79 million respectively. From the above discussion it is evident that the Sample Bank_3 has spent 50.87 percentages out of 100 percentages of the total amount of corporate social responsibility (CSR) program during the study period. So, it can be concluded that the corporate social responsibility (CSR) contribution of Sample Bank_3 is better than that of the remaining sample banks. To examine whether there is any significant difference between the total corporate social responsibility (CSR) contributions of the sample banks during the years from 2012 to 2016 researchers have developed null hypothesis: Ho1: There is no significant difference between the total corporate social responsibility (CSR) contributions of the sample banks. For this purpose researchers conducted a paired sample t test (sample wise and year wise) and the results have shown in the following Tables:

Table 2: Table showing the sample wise results of $t$ test of the total contributions under corporate social responsibility (CSR) program of the sample banks

\begin{tabular}{|c|c|c|c|}
\hline Name of Sample & Results of $\mathbf{t}$ value & Significance level & Decisions \\
\hline S_1 vs. S_2 & -0.977 & 0.384 & Non Significant \\
\hline S_1 vs. S_3 & -1.525 & 0.202 & Non Significant \\
\hline S_1 vs. S_4 & 2.080 & 0.106 & Non Significant \\
\hline S_2 vs. S_3 & -1.574 & 0.191 & Non Significant \\
\hline S_2 vs. S_4 & 4.820 & 0.009 & Significant \\
\hline S_3 vs. S_4 & 2.047 & 0.110 & Non Significant \\
\hline Average & 0.811 & 0.167 & Non Significant \\
\hline
\end{tabular}

(Source: Compilation of Annual Reports of Sample Banks)

Table 2 reveals the results of $t$ value and it significance level of sample wise $t$ test of the total contributions under corporate social responsibility (CSR) program of the sample banks during the years from 2012 to 2016. The average $t$ value is 0.811 and it significance level is 0.167 which means that the null hypothesis is accepted in maximum cases. This means that there is no significant difference between the total corporate social responsibility (CSR) contributions of the sample banks during the study period.

Table 3 presents the results of $t$ value and it significance level of year wise $t$ test of the total contributions under corporate social responsibility (CSR) program of the sample banks in the different years. The average $t$ value is 0.381 while that for significance level is 0.237 . The 
results reveal that the null hypothesis is accepted in maximum cases and also mention that there is no significant difference between the corporate social responsibility (CSR) contributions in the different years of the sample banks.

Table 3: Table showing the year wise results of $t$ test of the total contributions under corporate social responsibility (CSR) program of the sample banks

\begin{tabular}{|c|c|c|c|}
\hline Selected Years & Results of $\mathbf{t}$ value & Significance level & Decisions \\
\hline 2012 vs. 2013 & -1.600 & 0.208 & Non Significant \\
\hline 2012 vs. 2014 & -6.065 & 0.009 & Significant \\
\hline 2012 vs. 2015 & 0.739 & 0.514 & Non Significant \\
\hline 2012 vs. 2016 & 1.649 & 0.198 & Non Significant \\
\hline 2013 vs. 2014 & 1.218 & 0.310 & Non Significant \\
\hline 2013 vs. 2015 & 1.283 & 0.290 & Non Significant \\
\hline 2013 vs. 2016 & 1.623 & 0.203 & Non Significant \\
\hline 2014 vs. 2015 & 1.317 & 0.279 & Non Significant \\
\hline 2014 vs. 2016 & 2.207 & 0.114 & Non Significant \\
\hline 2015 vs. 2016 & 1.436 & 0.247 & Non Significant \\
\hline Average & 0.381 & 0.237 & Non Significant \\
\hline
\end{tabular}

(Source: Compilation of Annual Reports of Sample Banks)

\section{REGRESSION ANALYSIS}

The following results of regression analysis of the sample banks in the respective years from 2012 to 2016 have obtained by using the SPSS program.

Ho2.1: There is no influence of net profit on corporate social responsibility (CSR) expenditures of the sample banks over the study period.

Table 4: Table showing the results of Regression (CSR expenditures vs. Net Profit)

\begin{tabular}{|c|c|c|c|c|}
\hline Sample Banks & $\mathrm{R}^{2}$ & F ratio & Significance Level & Decisions \\
\hline Sample Bank_1 & 0.129 & 0.445 & 0.552 & Non Significant \\
\hline Sample Bank_2 & 0.204 & 0.770 & 0.445 & Non Significant \\
\hline Sample Bank_3 & 0.057 & 0.182 & 0.698 & Non Significant \\
\hline Sample Bank_4 & 0.094 & 0.298 & 0.623 & Non Significant \\
\hline
\end{tabular}

(Source: Compilation of Annual Reports of Sample Banks)

Table No. 4 shows the results of regression analysis of the sample banks between the study periods from 2012 to 2016. From the above table it is observed that the null hypothesis is accepted in all cases which mean that there is no influence of net profit on the corporate social responsibility expenditures (CSR) program of the sample banks during the study period.

Ho2.2: There is no influence of deposits on corporate social responsibility (CSR) expenditures of the sample banks over the study period.

Table 5: Table showing the results of Regression (CSR expenditures vs. Total Deposits)

\begin{tabular}{|c|c|c|c|c|}
\hline Sample Banks & $\mathrm{R}^{2}$ & F ratio & Significance Level & Decisions \\
\hline Sample Bank_1 & 0.050 & 0.157 & 0.719 & Non Significant \\
\hline Sample Bank_2 & 0.506 & 3.075 & 0.178 & Non Significant \\
\hline Sample Bank_3 & 0.380 & 1.839 & 0.268 & Non Significant \\
\hline Sample Bank_4 & 0.152 & 0.537 & 0.517 & Non Significant \\
\hline
\end{tabular}

(Source: Compilation of Annual Reports of Sample Banks) 
Table 5 presents the regressional results of the sample banks and it can be seen from the aforesaid table that the null hypothesis is accepted in all cases which mean that there is no influence of total deposits on the corporate social responsibility (CSR) expenditures of the sample banks over the study period.

Ho2.3: There is no influence of total assets on corporate social responsibility (CSR) expenditures of the sample banks over the study period.

Table 6: Table showing the results of Regression (CSR expenditures vs. Total Assets)

\begin{tabular}{|c|c|c|c|c|}
\hline Sample Banks & $\mathrm{R}^{2}$ & F ratio & Significance Level & Decisions \\
\hline Sample Bank_1 & 0.040 & 0.126 & 0.746 & Non Significant \\
\hline Sample Bank_2 & 0.517 & 3.214 & 0.171 & Non Significant \\
\hline Sample Bank_3 & 0.380 & 1.842 & 0.268 & Non Significant \\
\hline Sample Bank_4 & 0.017 & 0.051 & 0.836 & Non Significant \\
\hline
\end{tabular}

(Source: Compilation of Annual Reports of Sample Banks)

Table 6 reveals the results of regression analysis of the sample banks over the study period. Based on the above results it can be concluded that the null hypothesis is accepted in all cases which means that there is no influence of total assets on the corporate social responsibility (CSR) expenditures of the sample banks during the study period.

Hoz.4: There is no influence of total investments on corporate social responsibility (CSR) expenditures of the sample banks over the study period.

Table 7: Table showing the results of Regression (CSR expenditures vs. Total Investments)

\begin{tabular}{|c|c|c|c|c|}
\hline Sample Banks & $\mathrm{R}^{2}$ & F ratio & Significance Level & Decisions \\
\hline Sample Bank_1 & 0.000 & 0.000 & 0.989 & Non Significant \\
\hline Sample Bank_2 & 0.598 & 4.457 & 0.125 & Non Significant \\
\hline Sample Bank_3 & 0.094 & 0.313 & 0.615 & Non Significant \\
\hline Sample Bank_4 & 0.150 & 0.528 & 0.520 & Non Significant \\
\hline
\end{tabular}

(Source: Compilation of Annual Reports of Sample Banks)

Table 7 depicts the regressional results of the sample banks over the study period. From the above results it is found that the null hypothesis is accepted in all cases which mean that there is no influence of total investments on the corporate social responsibility (CSR) expenditures of the sample banks over the study period.

Ho2.5: There is no influence of return on assets (ROA) on corporate social responsibility (CSR) expenditures of the sample banks over the study period.

Table 8: Table showing the results of Regression (CSR expenditures vs. ROA)

\begin{tabular}{|c|c|c|c|c|}
\hline Sample Banks & $\mathrm{R}^{2}$ & F ratio & Significance Level & Decisions \\
\hline Sample Bank_1 & 0.136 & 0.473 & 0.541 & Non Significant \\
\hline Sample Bank_2 & 0.127 & 0.436 & 0.556 & Non Significant \\
\hline Sample Bank_3 & 0.061 & 0.193 & 0.690 & Non Significant \\
\hline Sample Bank_4 & 0.036 & 0.112 & 0.760 & Non Significant \\
\hline
\end{tabular}

(Source: Compilation of Annual Reports of Sample Banks)

Table 8 shows the results of regression analysis of the sample banks over the study period. From the above results it is evident that the null hypothesis is accepted in all cases which mean that there is no influence of return on assets (ROA) on the corporate social responsibility (CSR) expenditures of the sample banks over the study period. 
Ho2.6: There is no influence of return on equity (ROE) on corporate social responsibility (CSR) expenditures of the sample banks over the study period.

Table 9: Table showing the results of Regression (CSR expenditures vs. ROE)

\begin{tabular}{|c|c|c|c|c|}
\hline Sample Banks & $\mathrm{R}^{2}$ & F ratio & Significance Level & Decisions \\
\hline Sample Bank_1 & 0.137 & 0.477 & 0.540 & Non Significant \\
\hline Sample Bank_2 & 0.123 & 0.419 & 0.564 & Non Significant \\
\hline Sample Bank_3 & 0.059 & 0.187 & 0.695 & Non Significant \\
\hline Sample Bank_4 & 0.031 & 0.097 & 0.776 & Non Significant \\
\hline
\end{tabular}

(Source: Compilation of Annual Reports of Sample Banks)

Table 9 reveals the regressional results of the sample banks over the study period. It is apparent from the above table that the null hypothesis is accepted in all cases which means that there is no influence of return on equity (ROE) on the corporate social responsibility (CSR) expenditures of the sample banks over the study period.

Ho2.7: There is no any influence of earnings per share on corporate social responsibility (CSR) expenditures of the sample banks over the study period.

Table 10: Table showing the results of Regression (CSR expenditures vs. EPS)

\begin{tabular}{|c|c|c|c|c|}
\hline Sample Banks & $\mathrm{R}^{2}$ & F ratio & Significance Level & Decisions \\
\hline Sample Bank_1 & 0.144 & 0.505 & 0.529 & Non Significant \\
\hline Sample Bank_2 & 0.130 & 0.448 & 0.551 & Non Significant \\
\hline Sample Bank_3 & 0.103 & 0.344 & 0.599 & Non Significant \\
\hline Sample Bank_4 & 0.047 & 0.150 & 0.725 & Non Significant \\
\hline
\end{tabular}

(Source: Compilation of Annual Reports of Sample Banks)

Table 10 make known the results of regression analysis of the sample banks over the study period. It is capable of being easily understood from the above table that the null hypothesis is accepted in all cases which mean that there is no influence of earnings per share on the corporate social responsibility (CSR) expenditures of the sample banks over the study period.

Ho2.8: There is no any influence of all financial variables (net profit; total deposits; total assets; total investments; return on assets; return on equity and earnings per share) on corporate social responsibility (CSR) expenditures of the sample banks over the study period.

Table 11: Table showing the results of Regression (CSR expenditures vs. All Variables)

\begin{tabular}{|c|c|c|c|c|}
\hline Sample Banks & $\mathrm{R}^{2}$ & F ratio & Significance Level & Decisions \\
\hline Sample Bank_1 & 1.000 & 0.000 & 0.000 & Significant \\
\hline Sample Bank_2 & 1.000 & 0.000 & 0.000 & Significant \\
\hline Sample Bank_3 & 1.000 & 0.000 & 0.000 & Significant \\
\hline Sample Bank_4 & 1.000 & 0.000 & 0.000 & Significant \\
\hline
\end{tabular}

(Source: Compilation of Annual Reports of Sample Banks)

Table 11 discloses the results of regression analysis of the sample banks over the study period. From the above table it is visible that the null hypothesis is rejected in all cases which mean that there is influence of all financial variables (net profit; total deposits; total assets; total investments; return on assets; return on equity and earnings per share) on the corporate social responsibility (CSR) expenditures of the sample banks over the study period. 


\section{CONCLUSION}

The demand for performing social activities termed corporate social responsibility (CSR) by the firms is increasing rapidly and it take eagerly all organizational activities relating to the organization and society. So, corporate social responsibility (CSR) has become an eyecatching issue that has increasingly attracted the attention of the businesses, political persons, academicians and researchers (Sufian, 2012). In recent years, customers, employees, suppliers, community groups, governments and some shareholders have encouraged firms to undertake additional investments in corporate social responsibility (CSR). Some firms have responded to this concern by devoting more resources to corporate social responsibility (CSR) program. Investment in corporate social responsibility (CSR) activities promotes product differentiation at the product and firm levels. Some firms will produce goods or services with attributes or characteristics that signal to the consumer that the company is concerned about certain social issues (Mcwilliams and Siegel, 2000). This research study has created attempt to evaluate the total corporate social responsibility (CSR) expenditures and its relationship with financial performance variable of the sample nationalized commercial banks in Bangladesh. From the above discussion it is evident that the sample banks have contributed in the different activities of corporate social responsibility (CSR) program but the contributions were not significant during the study period. The average corporate social responsibility (CSR) expenditures of the sample banks in case of respective years were very poor during the study period. The above discussion revealed that the total corporate social responsibility (CSR) expenditures of the sample banks has shown increasing and decreasing tendency during the study period. The study stated that the sample bank_3 has contributed more amounts in the different activities of corporate social responsibility (CSR) program and the sample bank_4 has contributed poor amounts in the different activities under the corporate social responsibility (CSR) program during the study period. In addition, there is no significant influence the different financial performance variables on corporate social responsibility (CSR) expenditures of the sample banks. At present corporate social responsibility (CSR) has become the demanding issues in business and it is essential to run long term business and sustainable growth and success. This present research study suggests that proper guideline and financial independence as well as transparency and accountability regarding the different activities of corporate social responsibility (CSR) program is indispensable for ensuring the public interest, social benefit and protection of environment.

\section{REFERENCES}

Abiodun (2012), "The Impact of Corporate Social Responsibility on Firms' profitability in Nigeria", European Journal of Economics, Finance and Administrative Sciences, Issues 45.

Ahmed AAA. 2009. The Effect of Timeliness Regulation of Corporate Financial Reporting: Evidence from Banking Sector of Bangladesh Accounting and Management Information Systems, 8, 216 - 235.

Ashraf, Khan and Tariq, (2017), "Corporate Social Responsibility Impact on Financial Performance of Bank's: Evidence from Asian Countries", International Journal of Academic Research in Business and Social Sciences, Vol. 7, No. 4.

Begum R, Ahmed AA and Neogy TK. 2012. Management Decisions and Univariate Analysis: Effects on Corporate Governance in Bangladesh Journal of Business Studies, 3, 87-115.

Ferdous (2015), "Corporate Social Responsibility Practices in Bangladesh: An Assessment of Four StateOwned Commercial Banks (SoCBS)", International Journal of Business, Economics and Law, Vol. 8, Issue 2, December. 
Ferdous and Moniruzzaman (2013), “An Empirical Evidence of Corporate Social Responsibility by Banking Sector Based on Bangladesh", Asian Business Review, Volume 2, Number 3.

Ferdous, M., \& Moniruzzaman, M. (2013). An Empirical Evidence of Corporate Social Responsibility by Banking Sector based on Bangladesh. Asian Business Review, 3(2), 74-79. https://doi.org/10.18034/abr.v3i2.90

Giannarakis, Konteos, Zafeiriou and Partalidou (2016), “The Impact of Corporate Social Responsibility on Financial Performance", Journal of Investment Management and Financial Innovations, Volume 13, Issue 3.

Gololo (2016), “Corporate Social Responsibility and Financial Performance of Some Selected Banks in Nigeria: An Empirical Analysis", The Millennium University Journal, Vol. 1, no. 1.

Haldar and Rahman (2015), “Assessing Impact of Corporate Social Responsibility on Bank Performance in Bangladesh: A Study on Some Selected Banks", Journal of Business and Technology (Dhaka), Volume-X, No.-02, July-December.

Hossain and Sultana (2014), "Regulatory Compliance of IFRS \# 7 of the Private Commercial Banks Disclosure of Bangladesh: An Empirical Study on Ten Selected Banks", World Vision Research Journal, vol. 8, No. 1.

Islam, M. T., \& Hasan, M. T. (2016). Corporate Social Responsibility of Commercial Bank in Bangladesh: A Comparative Study on Nationalized and Private Banks. Asian Business Review, 6(1), Art. \#4, pp. 25-34. https:/ / doi.org/10.18034/abr.v6i1.23

Kesto, D. A., \& Ravi, J. (2017). Corporate Social Responsibility Practices and Stakeholders' Awareness. ABC Journal of Advanced Research, 6(1), 41-52.

Khatun, (2014), "Corporate Social Responsibility in Bangladesh: The Law and Practices", Journal of Law, Policy and Globalization, Vol. 31.

Mcwilliams and Siegel (2000), "Corporate Social Responsibility and Financial Performance: Correlation or Mis-Specification?", Strategic Management Journal, Vol. 21, No. 5, May.

Mishra and Suar, (2010), “Does Corporate Social Responsibility Influence Firm Performance of Indian Companies?", Journal of Business Ethics, 95.

Mohammad and Kamal (2016), "Social Impact and Sustainability of Corporate Social Responsibility in the Banking Sectors: Bangladesh Perspective", Asian Business Review, Volume 6, Number 1.

Mohammad, N., \& Kamal, S. (2016). Social Impact and Sustainability of Corporate Social Responsibility in the Banking Sectors: Bangladesh Perspective. Asian Business Review, 6(1), Art. \#6, pp. 39-46. https://doi.org/10.18034/abr.v6i1.25

Roy, Sarker and Chowdhury (2017), "Corporate Social Responsibility Practices in Bangladesh: A Statistical Analysis on State-Owned \& Private Commercial Banks", Economics World, JulyAugust, Vol. 5, No. 4.

Sufian (2012), "Corporate Social Responsibility Disclosure in Bangladesh", Global Journal of Management and Business Research, Volume 12, Issue 14, Version 1.

Yesmine and Bhuiyah (2015), "Corporate Social Responsibility Practices in Bangladesh: Evidence from Engineering and Pharmaceutical \& Chemical Industry", International Journal of Business and Management Invention, Volume 4, Issue 10, October. 